ment. Early in the Second World War he suffered the grievous loss of his son, who was killed in his first operational flight as an observer in the Royal Air Force.

Throughout his scientific career Ashby was thorough and reliable in his work. His first research concerned the assimilation of nitrogen by a soil bacterium. In Jamaica he studied banana diseases and within six months published a valuable account of the work in the Bulletin of the Department in 1912, including a section on Panama disease. For the control of the disease he recommended the isolation of all infected areas, the boundary being set one chain distant from the nearest diseased plant. This treatment was immediately successful and no diseased plants were found outside the boundary line seven to nine months after treatment. Every diseased tree within the affected area was cut down, the stool dug up, and the whole burnt. There is no question but that Ashby's prompt and sound action saved the Jamaica banana industry from ruin and allowed the farmer a means of keeping the disease in check. Unhappily, in the course of years farmers became impatient at having to leave so much land out of cultivation and ultimately Ashby's policy had to be moderated and finally abandoned as the disease gradually got out of control. If his method had been consistently followed the progress of Panama disease would have been impeded much more than it actually was; but in any event, the slowing up of the spread of the disease allowed planters valuable time to consider alternative crops. While in Jamaica, Ashby also published in 1920 notes on a disease of coconut caused by $P$. palmivora and another by $P$. parasitica, and in 1921 an account of sugar-cane mosaic.

Throughout his life he maintained his interest in the important genus Phytophthora. In 1925 he became interested in Stilbum flavidum on coffee and succeeded in isolating and growing the fungus in culture, proving conclusively that the Stilbum is a state of the perfect form Omphalia flavida. In 1926 he published with W. Nowell a joint study on the fungi of Stigmatomycoses, a classic paper on a peculiar group of fungi attacking cotton bolls, one of which, since named Eremothecium asbyi, proved during the War to be a producer of riboflavin. His next important contribution was on bacterial wilt of bananas, which he showed was due to Bacterium solanacearum (Kew Bull., 14; 1927). In 1929 Mr. Ashby visited Dominica in connexion with the outbreak of red rot disease of limes and was able to assure the authorities that the prevalent fungus Sphaerostilbe repens had been present in the island since 1911 and was not a virulent pathogen. On his return he concluded an important paper on leaf scald of sugar-cane, naming the causal organism Bacterium albilineans. Two papers on Phytophthora followed, concerned with the production of sexual organs, and one on Gloeosporium strains isolated from bananas. When Mr. Ashby retired in 1939 he had accumulated on behalf of correspondents a vast amount of knowledge about the genus Phytophthora; but he did not put this information in print. $\mathrm{He}$ died on March 6 after a prolonged period of illness and is survived by his widow and one son. S. P. WIITSHIRE

\section{Mr. J. G. R. Elbo}

John Gregers Rosenstand Elbo died on March 11 at Carlton, near Cambridge, at the early age of thirty-one. He joined the staff of the Scott Polar Research Institute in 1946 as part-time assistant in Scandinavian studies, and specialized in the problems of northern Scandinavia, Svalbard and Greenland. He took his degree in modern languages at Cambridge in 1950, and then decided to study for a research degree in Eskimo philology. Meanwhile, the first sign of serious illness had become evident as early as 1948; despite apparently successful treatment his health slowly deteriorated, until in September 1953 the last illness began.

WE regret to announce the following deaths :

Mr. Roland Austin, during 1927-48 joint editor of Antiquity, aged seventy-nine years.

Mr. E. Graham Clark, C.B.E., secretary of the Institution of Civil Engineers, a post from which he was due to retire this year (see Nature, March 6, p. 427), on April 23, aged sixty-four.

Prof. Methodi Popov, director of the Institute of Biology, University of Sofia, on April 20, aged seventy-three.

\section{NEWS}

The Australian Academy of Science

The Australian Academy of Science was founded in 1952 (Nature, 170,549 ; 1952); on February 16, H.M. the Queen, during her visit to Australia, presented a Royal Charter to the officers and Councilelect of the Academy. This is the first time in nearly 300 years that a reigning British sovereign has founded a scientific society, the only previous occasion being the founding of the Reyal Society of London by Charles II. The names of the Council-elect are announced in the Australian Journal of Science for February; these have to be ratified at the first general meeting of the Academy during April 6-7 when twenty-seven new Fellows will be elected. Also to be ratified at the meeting are the nominations of the following officers: President, Prof. M. L. Oliphant; Treasurer, H. R. Marston; Secretary (Physical Sciences), Dr. D. F. Martyn; Secretary (Biological Sciences), Dr. A. J. Nicholson.

\section{and VIEW S}

\section{New Zealand Science Review}

To commemorate the recent visit of H.M. the Queen and H.R.H. the Duke of Edinburgh, the January issue of the New Zealand Science Review is a "Royalty and Science" number (12, 1; 1954). After a brief editorial article welcoming the Royal couple, the address entitled "Science and the Scientific Worker" given by the Duke before New Zealand scientists on January 13 is reported in full. This meeting was organized by the Royal Society of New Zealand, with its president, Dr. W. R. B. Oliver, in the chair. During his speech, the Duke conveyed greetings to the Royal Society of New Zealand from the Royal Society of London and the British Association for the Advancement of Science. Then follows an informative article reviewing the history of the interest shown by royalty in science. I. D. Dick contributes a more specialized article on "Royalty and Science in New Zealand". It was also a happy 